\title{
WEST GERMANY'S NEUE FRAUENBEWEGUNG AND THE PRODUCTIVE POTENTIAL OF FEMINIST (GEGEN)GEWALT
}

\section{CLARE BIELBY}

\begin{abstract}
This article explores the feminist potential of (Gegen)gewalt ((counter-)violence) during the founding years of West Germany's neue Frauenbewegung: firstly, as a discourse and practice which helped create the discursive space to start imagining feminist identity in the late 1960s, when, it has been argued, no such identity existed; secondly, as a militant practice in the early 1970s, through which women were able to change their gendered behavioural scripts in positive feminist ways; finally, as feminist self-defence, understood as enabling women to continue to imagine an active subject position in the mid-1970s, when women as the victims of patriarchal violence had become the predominant idea of the movement. Reading feminist flyers, publications and other documents of the period, as well as more recently published accounts of the movement, alongside the wider discourse on (Gegen)gewalt of the 1960s and 1970s, I trace a cultural history of feminist (Gegen)gewalt.
\end{abstract}

Keywords: Germany; violence; die neue Frauenbewegung; militancy; 1970s; antiauthoritarian student movement

(GEGEN)GEWALT WAS a central idea for the West German antiauthoritarian movement of the late 1960s and the movements that developed out of it. This article seeks to delineate a feminist discourse and practice of (Gegen)gewalt during the early years of what is most often referred to as West Germany's neue Frauenbewegung, ${ }^{1}$ itself rooted in the wider antiauthoritarian movement. According to most accounts, the neue Frauenbewegung should be traced back to September 1968, specifically to Sigrid Rüger's spectacular lobbing of tomatoes at male delegates at the $23^{\text {rd }}$ conference of the Sozialistischer Deutscher Studentenbund (SDS), West Germany's foremost socialist student organization and a key player in the antiauthoritarian movement. Reading the Tomatenwurf as a founding moment of feminist (Gegen)gewalt, I trace a cultural history of that discourse and practice from 1968 to the late 1970s: roughly speaking, the neue Frauenbewegung's period of 'Bewusstwerdung' and 'Artikulation'. ${ }^{2}$ My focus is on the productive and transformative potential of feminist (Gegen)gewalt for the nascent feminist subject and movement. 
Transforming oneself was an important notion in the wider context of antiauthoritarianism in the late 1960s, in West Germany and beyond. ${ }^{3}$ It has been argued that women were far more successful than their male counterparts in this regard: according to 68erin Sarah Haffner, 'Frauen [waren] der revolutionärste Teil dieser etwas revolutionären Bewegung [...], weil sie wirklich ihre eigene Situation stark infrage gestellt haben.' ${ }^{4}$ Ute Kätzel supports this reading: 'Tatsächlich wollten die Frauen nicht nur die Gesellschaft verändern, sondern in erster Linie sich selbst und ihre eigene Rolle, im Gegensatz zu den meisten Männern. ${ }^{5}$ Whilst there was a wider discourse on violence as (personally) transformative within the antiauthoritarian movement, (Gegen)gewalt could be particularly productive and transformative for female subjects, as this article will demonstrate in three ways. In the first section, I explore (Gegen)gewalt as feminist discourse and practice which helped create the discursive space to start imagining feminist identity in the late 1960s - a time when, it has been argued, no such identity existed. In the second, I consider (Gegen)gewalt as a militant practice in the early 1970s, through which women were able to change their gendered behavioural scripts in positive feminist ways. Finally, in the third section, I look at feminist self-defence as a redisciplining of the gendered body that enabled women to continue to imagine an active subject position in the mid-1970s - a time when the neue Frauenbewegung overwhelmingly understood women as the victims of patriarchal violence. Whilst I acknowledge that acts of violence are of course very different to talking or writing about them, I shall not be differentiating between actions and discourse: following Foucault, I understand words and discourse as, themselves, an event or a kind of 'doing', with real material effects, albeit that those effects are usually less immediate.

My sources are a combination of feminist flyers, publications and other documents of the period, as well as more recently published accounts of the movement by (former) activists. Although some of these documents are relatively well known, the vast majority are not: some are accessible through published collections of feminist texts; others can be found in various feminist and social history archives. ${ }^{6}$ Whilst it would be interesting to have considered other sources, such as feminist fiction of the 1970s - and my thoughts on feminist (Gegen)gewalt could be equally well applied here - this was unfortunately beyond the scope of this article. I read my material alongside the wider discourse on (Gegen)gewalt of the late 1960s and 1970s, a discourse inspired by theorists such as Frantz Fanon and Herbert Marcuse, ${ }^{7}$ and championed in the late 1960 s by student leader Rudi Dutschke ${ }^{8}$ and - at this point still left-wing journalist - Ulrike Meinhof. ${ }^{9}$ In broad terms, Gegengewalt was posited as a legitimate and necessary response to the Gewalt of the state and of Western imperialism, seen as both physically violent (the war in Vietnam; the police killing of student demonstrator Benno Ohnesorg in June 1967), and systemically and/or structurally violent, with capitalism itself understood as violent. Gegengewalt, used alongside 
terms such 'Notwehr' and the heroically-connoted 'Widerstand', was thus posited as a reactive rather than active force, even as self-defence. ${ }^{10}$ It was also framed as something positive; activists applied terms such as 'aufklärerische Gewalt' and 'befreiende Gewalt' to their political practice. ${ }^{11}$ I seek to gender the notion of (Gegen)gewalt, as well as to uncover a specifically feminist discourse on it. (Gegen)gewalt, I argue, was a transformative and empowering force for female and/or feminist subjects. This needs acknowledging, particularly in a context in which the ambivalence of West German feminists' relationship to Gewalt tends, to be 'written out' of the historiography and cultural memory of the neue Frauenbewegung with, at times, far-reaching scholarly, political and ethical implications, as Patricia Melzer has recently demonstrated. ${ }^{12}$

According to Melzer, primarily as a result of the cultural feminist position that developed from the mid-1970s onwards in West Germany - a position that sees violence as inherently masculine and patriarchal, and women as inherently non-violent - the idea emerged that the only feminist resistance possible is a non-violent one, in a context in which 'women's relationship to violence is necessarily one of oppression' (DSYG, 233). ${ }^{13}$ As Melzer argues, this position has led to 'the historical separation of feminist politics and violence' and to 'the necessary discounting of any violent resistance as nonfeminist' (DSYG, 36 and 235). One result of this is that certain women, such as those of the militant feminist group Rote Zora, have even been written out of feminism. ${ }^{14}$ Perhaps more significantly, the notion that feminist politics can only be non-violent has meant that for a long time West German feminists, amongst others, did not reflect on their own racial and class privilege and engage with women in other contexts, for whom violent resistance might be a more urgent need. 'An assumed peaceful disposition,' Melzer argues, 'releases Western women from examining calls for solidarity and their own privilege, which allows a pacifist strategy. Instead of constituting an ahistoric, universal truth, women's presumed nonviolence is actually a discursively produced assumption based on the privileging of specific voices and actions' (DSYG, 234).

As well as contributing to the important scholarly, political and ethical task of writing violence back into the neue Frauenbewegung, this article is situated in the context of research into violence that focuses on violence's productive, rather than merely destructive tendencies, and which seeks to engage with the question of why the practice of violence might be attractive. ${ }^{15}$ In this way the article is concerned with what have been termed expressive or phatic uses of violence, where violence is understood not just as aimed at an enemy but also as 'affirm[ing] a way of life'. ${ }^{16}$ I will be using the German terms Gewalt and Gegengewalt throughout since Gewalt has additional meanings to that of 'violence' in English: Gewalt also means 'force' and 'legitimate state power' (as in the term 'staatliches Gewaltmonopol', theorized by German sociologist Max Weber). Hence, what precisely leftist (feminist) activists mean when they 
discuss the Gewalt of the state and their own (Gegen)gewalt goes beyond what we would understand by 'violence'.

\section{'Gegengewalt' and finding the feminist subject}

In June 1969, philosopher Karin Schrader-Klebert published an article entitled 'Die kulturelle Revolution der Frau' in the left-wing journal Kursbuch, ${ }^{17}$ an article that was celebrated by those on the left and retrospectively declared a feminist 'milestone' by West Germany’s most prominent feminist, Alice Schwarzer, in $1981 .{ }^{18}$ On the opening page, Schrader-Klebert asserts:

Die Frauen sind die Neger aller Völker und der kollektiven Geschichte. Für die Neger wie für die Frauen geht es jetzt darum, die Geschichte der Gewaltanwendung zu erkennen und die Gewalt, deren Produkt sie sind, gegen die Unterdrücker selbst zurückzuwenden, sich vom Status des Opfers und Objekts in den des Subjekts und Handelnden zu versetzten. (KRF, 1-2)

Conflating one's own position with that of those persecuted due to their race/ethnicity was a common and problematic technique in the antiauthoritarian movement, indicative not least of the enthusiastic interest in militant black Americans in the late 1960s and beyond. This interest can be partly explained by the presence of black American GIs stationed in postwar West Germany, but there was more to it than that. As Detlef Siegfried explains in a quotation which, though attentive to race, is gender blind: 'Since a revolutionary subject was hardly to be found in West Germany, aspirations were commonly projected onto African-American ghetto dwellers, who, during the summer of 1967 [...] renewed their violent confrontation with the state' after certain activists had formed the militant organization the Black Panther Party in $1966 .{ }^{19}$ Although Schrader-Klebert equates the situation of women and Afro-Americans - referring to the latter using the racist term 'Neger' ${ }^{20}$ - she does at least acknowledge differences in their respective positions. ${ }^{21}$ These differences notwithstanding, Gewalt clearly plays an important role for Schrader-Klebert in the process of women and people of colour becoming subjects and historical and political agents. Women and people of colour must turn the Gewalt that supposedly constitutes them back on the oppressor, she argues.

Understanding oneself as a self-consciously female political subject, let alone as a feminist, was by no means self-evident in the late 1960s, as members of the neue Frauenbewegung have since discussed. Ute Kätzel, editor of Die 68erinnen (2002), describes how there was no established female political identity, so little discursive space to imagine political women as women at the time: 'eine neue, positive Frauenidentität musste erst geschaffen werden’; ‘Ein positives weibliches Rollenmodell existierte damals noch nicht. Daher 
identifizierten sich viele Aktivistinnen nicht als Frauen, sondern - vermeintlich geschlechtsneutral - als Menschen.' ${ }^{22}$ Numerous West German feminists have reflected on how they were unaware of an earlier 'first wave' of feminist women in Germany who, according to Alice Schwarzer, had been written out of history and so had to be 'rediscovered' ${ }^{23}$ Helke Sander demonstrates this lack of awareness in one of the earliest texts produced by the Aktionsrat zur Befreiung der Frau, the left-wing women's group that formed in West Berlin in late 1967/early 1968 and constituted 'one of the first efforts to organise more broadly around women's issues' $(D S Y G, 59)$ in the postwar Federal Republic. As Sander explains in February 1968:

[Der mann] hört noch den ruf der geschichte, denn sie ist bisher von ihm und für ihn gemacht worden. die frauen irren heimatlos in diesem system umher [...] sie sind niemals dazu aufgefordert worden, geschichte zu machen. ${ }^{24}$

Whilst men are interpellated as historical subjects in the Althusserian sense here, women have no direction, no sense of progress, no discursive space in this patrilineal construction of history they wander aimlessly around ('umherirren'); they are without 'Heimat'. Sander would later reflect: 'Viele von uns wussten gar nicht, dass es schon einmal eine Frauenbewegung gegeben hatte. ${ }^{25}$ As Alice Schwarzer argues, using naturalistic imagery to naturalize the feminist collective 'wir', this erasure of women's and feminist history is no small matter when it comes to the question of feminist subjectivity: 'Geschichte ist nicht nur Vergangenheit, sie ist auch Zukunft. Ohne Geschichte sind wir wurzel- und identitätslos. ${ }^{26}$

In her article, then, Schrader-Klebert starts to create that discursive space, and women's use of Gewalt plays a key role in this. Though she does not mention him, Schrader-Klebert is clearly influenced by the work of Frantz Fanon, the theorist and psychiatrist who treated both mentally and physically traumatized patients in French colonial Algeria. His 1961 text Les Damnés de la terre was published in German (as Die Verdammten dieser Erde) in 1966, and his theoretical importance for the antiauthoritarian movement was immense. ${ }^{27}$ Fanon's ideas on colonial Algeria and the particular experience of colonized Algerian men, however, were too often applied in unreflected ways to the very different context of West Germany. In the text, Fanon discusses how the native Algerian has internalized the colonial violence of the French oppressor and must use violence to reclaim a sense of self or subjectivity. Violence, here, is conceived of as a cleansing, humanizing and emancipatory force. Jean-Paul Sartre, who wrote the preface, asserts: 'The native cures himself of colonial neurosis by thrusting out the settler through force of arms. When his rage boils over, he rediscovers his lost innocence and he comes to know himself in that he himself creates his self. ${ }^{28}$ Fanon writes, drawing attention to the productive 
and transformative dimension to violence: 'because it constitutes their only work, [this violence] invests their characters with positive and creative qualities'; 'violence is a cleansing force. It frees the native from his inferiority complex and from his despair and inaction; it makes him fearless and restores his self-respect. ${ }^{29}$ Fanon writes only of male Algerians, gendering his subject masculine throughout, and at times alluding to the constitutive power of violence to black colonized masculinity: 'Decolonialization,' he asserts, ‘is the veritable creation of new men. ${ }^{30}$ Sartre observes: '[T]his irrepressible violence [...] is man re-creating himself., 31

Without discussing gender, Sarah Colvin has shown how this Fanonian notion of violence as personally transformative is picked up in the wider antiauthoritarian movement, for example in the konkret article 'Gewalt' of June 1968, although the authors, like Schrader-Klebert, fail to mention Fanon explicitly. Nonetheless, his ideas clearly shape their reflections on the example of a black sniper in Detroit who shot at police, an action described as ‘unbeschreiblich schön'. 'Er machte sich in diesem Augenblick zu einem Menschen,' they assert approvingly; '[Er] stellte durch seinen Kampf einen Teil seiner verwüsteten Identität wieder her.' ${ }^{32}$ As Colvin argues, the authors understand this militant black American as a ‘model of self-realization' through violence for West Germans. ${ }^{33}$ They also suggest that similar transformations of the self can and are being achieved in West Germany through violent protest: 'Wir haben selbst die befreiende Wirkung der Widerstandsgewalt erfahren., 34

Echoing Fanon, Schrader-Klebert describes how women have internalized the male violence to which they have been subjected, a form of symbolic or psychological violence: '[S]ie [hat] die Gewalt verinnerlicht, die auf sie ausgeübt worden ist' (KRF, 7). That violence, however, lacks those immediately physical dimensions that Fanon also emphasizes with regard to colonial violence. The patriarchal Gewalt of 1960s’ West Germany is clearly less immediately physical. As for the female Gewalt put forward in response, Schrader-Klebert stops short of explicitly ascribing to it a humanizing, cleansing quality, but this quality is implicit: Gewalt is certainly posited as something empowering, emancipatory and transformative for women, as key to their claiming a sense of agency and their subject status as women. Furthermore, like Fanon, SchraderKlebert couches this violence in terms of counter-violence, Gegengewalt. The final section of the article has the title 'Das unglückliche Bewußtsein der Frau und das Problem der Gegengewalt' (KRF, 41-45). ${ }^{35}$ Schrader-Klebert opens it by asserting the crucial importance for a woman of gaining a sense of her own political identity and female subjectivity:

Der geschichtlich begründete Antagonismus zwischen Mann und Frau kann nur auf dem Wege einer Selbstbewußtwerdung und Politisierung der Frau überwunden werden, die sie selbst erreicht und 
durchführt. [...]. Die Frau muß sich erst einmal als selbstständiges, vom Mann unabhängiges Subjekt begreifen lernen. (KRF, 41)

She goes on to describe Gegengewalt as indispensable to this process and as essential to women's sense of their own agency and selfhood, their 'self-preservation' ('Selbsterhaltung') as subjects: 'Erst wenn die Frau in diese Dialektik von Geschichte und Handeln eintritt, kann sie sich das Problem der Gegengewalt als Problem ihrer Selbsterhaltung stellen’ (KRF, 44). In this context, and recalling Fanon, Gegengewalt becomes curative: 'Denn ein allgemeines Leiden läßt sich nicht durch Abwarten kurieren' (Ibid.; my italics).

Schrader-Klebert discusses the role played by emotions and affects here. The task, she asserts, is for women to channel their aggression outwards, instead of inwards and/or towards their children, and for women to politicize what they understand in individualized terms as 'das private Unglück’, grasping it instead as women’s ‘allgemeine Leiden’:

Die Aggressionen, die die Frau bisher gegen sich selbst, gegen Kinder gewendet und damit domestiziert hat, wird sie, wenn sie die Allgemeinheit ihres Problems erkennt, gegen die Gesellschaft, die Institutionen, gegen die Charaktermasken der überlegenen Männlichkeiten mobilisieren [...] sie wird sowohl bestehendes Scheinglück als auch das bloß private Unglück vieler zerrütteter Ehen und Gewohnheitsehen angreifen, das allgemeine Leiden in ihnen entlarven und damit Aktion und Gegengewalt für die Frau erst unumgänglich machen. [...] [S]obald das private Unglück als allgemeines Leiden erkannt ist, [ist] die Quelle der privaten Resignation zerstört: Das allgemeine Leiden wird für die unglückliche Subjektivität produktiv. Wir müssen es bewusst zum Motor unserer Verweigerung, unseres Ungehorsams, unserer Aufsässigkeit machen. (KRF, 43-44)

In this way, Schrader-Klebert is positing a change of emotional and affective scripts for women. A flyer likely to have been the first produced by the Aktionsrat zur Befreiung der Frau in January 1968 creates a strong sense that the potentially productive emotions and affects of anger and aggression in women at this time were lacking, or at least mischannelled. The wording of its title, 'wir sind neidisch und wir sind traurig gewesen', and the focus on these emotions, is strikingly non-combative, though the use of the perfect tense here does create a hint of feminist optimism that things might be changing. ${ }^{36}$ Nonetheless, the tone differs from the dynamic, combative, feminist aggression - note Schrader-Klebert’s use of military terminology ('mobilisieren’; 'angreifen') - being called for one year later as 'Motor unserer Verweigerung, unseres Ungehorsams, unserer Aufsässigkeit'. The metaphor of the engine, and the driving forward it suggests, enacted linguistically through the anaphoric 'unserer Verweigerung, unseres Ungehorsams, unserer Aufsässigkeit', contrasts powerfully with Sander's construction, in her text 
of February 1968, of women wandering aimlessly around ('umherirren’) in patrilineal history. ${ }^{37}$ Because of the changing of emotional scripts put forward by Schrader-Klebert, and the transformations of female selfhood they enable, Schrader-Klebert understands women to have truly radical potential: 'Darin liegt gerade ihre Chance, wirklich radikal zu werden: von sich selbst aus’' (KRF, 42).

Unlike Fanon, who makes no secret of the physical nature of the counter-violence he proposes, using a language of affect to emphasize this physical quality, Schrader-Klebert is highly evasive about what precise form Gegengewalt should take. At times she seems to be calling for a purely symbolic or metaphorical form, for example in her descriptions of how women should destroy existing social ties and norms. Elsewhere, though, she seems to be positing a more physical form of Gegengewalt: she describes 'de[n] Teufelskreis zwischen der Gewalt des ökonomischen Subjekts und der Unmündigkeit des Objekts [...], der nur mit Gewalt wieder sprengbar ist' (KRF, 9). Not least through the explosive quality of the verb 'sprengen', Gewalt here seems to have more physical resonances. Similarly, she discusses 'Aktionen’ and 'Gegengewalt' as necessary for women, but neither here, nor in the previous instance, does she provide any concrete examples.

In ways much less immediately bound up with subjectivity, and in gender-neutral terms, Ulrike Meinhof had been using the term Gegengewalt to conceptualize and justify the political activism of the antiauthoritarian movement. In February 1968, more than a year before the publication of Schrader-Klebert's text, Meinhof had written an article titled 'Gegen-Gewalt' in the left-wing journal konkret, in which she defended the actions of students in the form of disturbances - symbolic forms of Gegengewalt - during the matriculation ceremony at the University of Hamburg. ${ }^{38}$ By May 1968, Meinhof was justifying and praising protesters’ 'Widerstand' or 'Gegengewalt' in the form of 'Gewalt gegen Sachen' (the smashing of windows/vandalism) in her article 'Vom Protest zum Widerstand', written after Josef Bachmann's attempted assassination of Rudi Dutschke in April 1968 and the escalation of violence which followed. ${ }^{39}$ In this discursive context, it is possible that Schrader-Klebert means only symbolic Gegengewalt, but she could also mean 'Gewalt gegen Sachen', something 'widely accepted' by protesting students in the late 1960s. ${ }^{40}$ Whilst it is unlikely, it is also possible that she might even mean 'Gewalt gegen Personen’: Colvin has shown that the possibility of committing acts of Gewalt against people was being discussed by figures at the very centre of the '68 movement, including Meinhof, in the 'Gewalt' article of June $1968 .{ }^{41}$ It is a few months later that a feminist critique of masculine/macho militancy starts to develop. In a letter addressed to women comrades in the west, written in November 1968, the Aktionsrat zur Befreiung der Frau assert, invoking Freud: ‘[M]ilitante demonstrationen sind derart, dass sie bisher nur für männer 
sinnvoll sein können. aber auch dort scheint die militanz eher eine überich-funktion zu haben.’ Interestingly, though, the group does not rule out the possibility of feminist forms of militancy in the future: 'wir sind noch nicht in der lage, militant - besser effektiv - auf eine entsprechende weise zu sein’ (my italics). ${ }^{42}$

By referring to the 'Problem der Gegengewalt', Schrader-Klebert perhaps gestures towards an ethical understanding of the highly problematic nature of violence. However, she remains abstract and elusive, failing to take responsibility for her words: claiming that her text is merely 'agitatorisch' (KRF, 4), rather than a thorough and prescriptive analysis, does not seem enough given this wider context. Whatever her position, Schrader-Klebert's article is important for setting out a specifically female, even feminist, form of Gegengewalt that is emancipatory and productive: a means through which women can start to gain a sense of their own agency and subjectivity as women. Violence or Gegengewalt, as theorized here, has transformative potential for the nascent feminist self.

An incident that took place a few months prior to the publication of Schrader-Klebert's article, and which has gone down in history as the founding moment of West Germany's neue Frauenbewegung, ${ }^{43}$ could be seen as Gegengewalt as understood by Schrader-Klebert. At the $23^{\text {rd }}$ conference of the Sozialistischer Deutscher Studentenbund (SDS), which took place in Frankfurt am Main on 13 September 1968, SDSlerin Sigrid Rüger had pelted male delegates with tomatoes after they had refused to discuss a speech made by Helke Sander on behalf of the Aktionsrat zur Befreiung der Frau. In her speech, Sander had drawn attention to the specific situation of women, particularly mothers, in left-wing circles and in society more generally, and had argued for an expansion of 'the political' to encompass the private domain. Though not in terms of Gegengewalt, Sander also drew attention to the difficulty of finding a political identity as a woman, asserting: 'Frauen suchen ihre Identität. ${ }^{44}$

Schrader-Klebert, who attended the SDS conference and wrote her article shortly afterwards, does not refer to Rüger's so-called Tomatenwurf, but she does cite Helke Sander's speech at length in the final section of her article on Gegengewalt, thus positioning the incident in the context of Gegengewalt. ${ }^{45}$ Another person on whom the intervention seemingly made quite an impression was left-wing journalist and proponent of Gegengewalt herself, Ulrike Meinhof. Meinhof discusses Sander's speech and Rüger's Tomatenwurf in what is arguably her most feminist article: 'Die Frauen im SDS oder In eigener Sache’, published in konkret in October 1968. She situates the incident in the context of the antiauthoritarian movement's tendency to throw things, for example tomatoes and eggs. As she points out, though, when students had thrown food at the Shah of Persia during his visit in 1967, their actions had been symbolic, they 
had acted on behalf of others. Here women were operating in their own interests: 'in eigener Sache', overturning their status as objects and victims and claiming their agency:

Sie haben klargestellt, daß die Unvereinbarkeit von Kinderaufzucht und außerhäuslicher Arbeit nicht ihr persönliches Versagen ist, sondern die Sache der Gesellschaft, die die Unvereinbarkeit gestiftet hat. [...] Als die Männer darauf nicht eingehen wollten, kriegten sie Tomaten an den Kopf. Sie haben nicht rumgejammert und sich nicht als Opfer dargestellt, die Mitleid beantragen und Verständnis. ${ }^{46}$

Meinhof does not use the term Gegengewalt here, but she had used it to designate very similar practices - or symbolic uses of Gewalt - a few months earlier, in her 'Gegen-Gewalt' article of February 1968. There she had defended the actions of students (their 'Gegen-Gewalt' in the form of public disturbances) in the face of linguistic and institutional forms of 'Gewalt' ${ }^{47}$ That Meinhof describes similar actions as Gegengewalt in one context but not in another is instructive: clearly what counts as Gegengewalt depends on whether the Gewalt it is countering is conceived of as Gewalt in the first place. For Meinhof (and the vast majority of leftist activists at this time), the state was understood as inherently violent, but men were not - yet. The notion of an inherently violent patriarchal society had not yet been developed. It would take the interventions of the neue Frauenbewegung in the 1970s to arrive at this understanding, as I will go on to discuss. Hence, Schrader-Klebert was anticipating by several years the neue Frauenbewegung's 'discovery' and focus in the 1970s on the all-encompassing violence of patriarchal society.

Sigrid Rüger's spectacular example of feminist Gegengewalt ${ }^{48}$ certainly made an impression on other women (and would-be feminists) as well as on the mainstream press, ${ }^{49}$ thus extending its reach to other women and potential feminists. It also seemingly fortified the Berlin group itself. In a statement from October 1968, there is a clear sense of group identity and an assertiveness lacking from earlier documents: the first three paragraphs open with the pronoun 'wir' and the statement is buoyant in tone, expressed in short, punchy clauses. ${ }^{50}$ According to most histories of the neue Frauenbewegung, this intervention led left-wing women to return to their own cities and found their own feminist groups (Aktionsräte or Weiberräte). ${ }^{51}$ Indeed, seemingly inspired by the SDS conference, a group of leftist women in Frankfurt am Main calling itself the Aktionsrat zur Befreiung der Frau, Gruppe Frankfurt formed to undertake a militant feminist protest a few weeks later, in October 1968, at an event at the Frankfurt Paulskirche marking the fiftieth anniversary of women’s suffrage in Germany. According to a report published in the first ever Frauenjahrbuch (Frauenjahrbuch '75), the group had produced a flyer that they distributed during the event and tried to read out, but they were prevented from doing so by 'prügelnde SPD-Männer und Frauen'. ${ }^{52}$ According to mainstream press coverage, 
however, it was the women themselves who were violent. An article in the Frankfurter Rundschau describes 'heftige Auseinandersetzungen' and the fact that the mayor of Frankfurt was physically attacked whilst on the podium: 'Eine Studentin versuchte, ihm von hinten den Mund zuzuhalten, eine zweite zog ihn an den Haaren, eine dritte schließlich riß ihm das Mikrofon weg. 53

The group stayed together and, one month later in November 1968, now calling itself Weiberrat der Gruppe Frankfurt, gained notoriety at the next SDS delegate conference in Hanover by producing and distributing a now infamous flyer depicting a naked woman with an axe in her right hand, positioned below the severed penises of SDS male leaders, mounted on the wall (see Figure 1). The text reads: 'Befreit die sozialistischen Eminenzen von ihren bürgerlichen Schwänzen. ${ }^{54}$

According to the Frankfurt group, although many women delegates in Hanover reacted negatively at first to the aggression and violent imagery of the flyer, all eight women's groups present at the conference decided to support it after a conversation in which clear examples of the oppression described in the flyer had been discussed. This may be an overly optimistic reading. Certainly, former 68erinnen have retrospectively discussed how they found the flyer to be in very bad taste at the time. ${ }^{55}$ Either way, the group describes how the flyer and the discussion surrounding it had an impact on their political agency and how they were perceived by male comrades:

Wieder zu Hause wurde weitergearbeitet. Zum ersten Mal setzten sich die Genossinnen bei einer SDSMitgliederversammlung alle in einer Ecke zusammen und man konnte beobachten, daß dies von den Genossen wohl als Machtdemonstration begriffen wurde. Wenn eine Genossin einen Beitrag brachte, wurde ihr zugehört. Außerdem war sie selbst viel sicherer, weil sie die anderen Frauen hinter sich wußte und weil sie wußte, daß ihr notfalls eine andere weiterhelfen würde. ${ }^{56}$

The Tomatenwurf and flyer have been mythologized in feminist and more mainstream discourses as the founding moment of West Germany's neue Frauenbewegung. ${ }^{57}$ They appear to have had quite an effect on the possibilities certain women saw for their own political agency and political practices as women, empowering and mobilizing them to found their own women's and feminist groups, providing the discursive space to start to imagine political female and feminist identity in the earliest phase of the movement. With Schrader-Klebert, this can be read as feminist Gegengewalt which had productive and transformative potential for women and for nascent feminist subjects. 


\section{Militant violence as feminist '(Gegen)gewalt'}

The idea that the Tomatenwurf and events of 1968 constitute the founding moment of the neue Frauenbewegung, however, has been continually challenged by Alice Schwarzer, as well as by lesbian-feminist activist and filmmaker Cristina Perincioli. Both women tell a different story one that tends to emphasize their own role. According to Schwarzer, events in 1968 centred on a small, elitist group of leftist women; the neue Frauenbewegung started properly in 1971 with the prominent Stern-campaign around the continued criminalization of abortion: ${ }^{58}$ a campaign in which she played a central role. Schwarzer's desire to tell a different tale is evident in the title of her earliest retrospective text, So fing es an! 10 Jahre Frauenbewegung, tellingly published in $1981 .{ }^{59}$ In her recent book, Berlin wird feministisch: Das Beste, was von der 68er Bewegung blieb, and in other, shorter texts, ${ }^{60}$ Cristina Perincioli situates the start of the movement in 1973. The opening to the book makes this clear, as well as her desire to distinguish the movement from socialist women's groups in particular:

Um 1973 herum entwickelte sich in der Bundesrepublik Deutschland die feministische Bewegung; sie schuf Frauenzentren und innerhalb weniger Jahre Hunderte innovative Frauenprojekte. Im Gegensatz zu sozialistischen Frauengruppen war die feministische Bewegung basisdemokratisch und autonomy. (Bf, 7) ${ }^{61}$

In fact, it is not only socialist feminist groups that Perincioli writes out of the movement; she also attempts to write out prominent figures such as Helke Sander and Alice Schwarzer (ibid.), emphasizing instead the movement's anarchist origins, as well as the importance of lesbian feminists: ‘de[r] eigentliche [...] Motor der autonomen Frauenbewegung’ (Bf, 10). Arguably, Perincioli is responding to the reduction of the movement to figures such as Schwarzer and Sander, not least in the (West) German popular imagination, as well as to the representation of lesbian feminism as an ancillary component. I would argue that she is also responding to what Patricia Melzer, in Death in the Shape of a Young Girl, has diagnosed as a sort of writing out of discourses on violence, and of violent practices themselves, in the historiography and cultural memory of the neue Frauenbewegung.

Consistent with this reading, Perincioli seems keen to emphasize the importance of militant anarchist practices, particularly in the early 1970s, before the escalation of violence in groups such as the Rote Armee Fraktion and Bewegung 2. Juni greatly reduced the left's appetite for violent activism. For example, she makes frequent reference across her publications to Angela Luther and Verena Becker, members of her women's commune on Berlin's Cosimaplatz who would later become active in Bewegung 2. Juni. She also discusses a double-page feature in the 
anarchist publication Agit 883 of 16 April 1970, attributed to a group calling itself the 'Frauenbefreiungsfront' who call for militant action ('die Praxis') over theory. ${ }^{62}$ The double page includes images of, amongst others, Leila Khaled, a member of the Popular Front for the Liberation of Palestine, who hijacked several planes from 1969, and Valerie Solanas, who shot Andy Warhol and wrote the polemical SCUM [Society for Cutting up Men] Manifesto of 1967 (published in German as Manifest der Gesellschaft zur Vernichtung der Männer in 1969 by Märzverlag). ${ }^{63}$ The feature also includes two excerpts from that text, and the 'Frauenbefreiungsfront' ask 'Wo bleibt die Weiberbande?', before declaring: 'Die Frauenbefreiungsfront wird [...] Aktionen planen und ausführen und Zellen in der ganzen Stadt aufbauen. Sie wird aus dem Dunkel geräuschlos auftauchen, zuschlagen und wieder verschwinden.' The group signs off with the instructions: 'Männergewalt, überall, wo sie auftaucht, mit allen Mitteln angreifen. REVOLUTION BIS ZUM SIEG | MÄNNERGEWALT BEKÄMPFEN HEISST | DEM VOLKE DIENEN. ${ }^{64}$ Like Schrader-Klebert, the 'Frauenbefreiungsfront' is anticipating what will become the neue Frauenbewegung's focus on male violence, even rendering violence linguistically inseparable from men through the compound noun 'Männergewalt'. Citing Mao Tse-Tung by ending with the words 'dem Volke dienen', ${ }^{65}$ they also anticipate the title of the Rote Armee Fraktion's third position paper, 'Dem Volk dienen: Stadtguerilla und Klassenkampf' of $1972 .{ }^{66}$ It would be one month after the publication of this double-page feature in Agit 883 that Ulrike Meinhof and Gudrun Ensslin, amongst others, would 'liberate’ Andreas Baader from prison in Berlin in May 1970, an event that has gone down in history as the 'Geburtsstunde' of the RAF. The above quotation therefore makes clear the shared discursive context and origins of these militant activists.

Seemingly following the instructions issued by the 'Frauenbefreiungsfront', Perincioli writes that she, too, engaged in militant activism on a regular basis $(B f, 42)$, drawing attention to the feminist motivation behind those violent practices that, she claims, were understood as feminist at the time:

Die militanten Aktionen unserer Frauenkommune sollten Frauenbelange verdeutlichen, sollten zeigen, dass es Frauen gibt, die für Frauen zu Mollis und zu Waffen greifen. Unsere Aktionen kamen gut an, selbst bei unpolitischen Frauen. Man akzeptierte militante Aktionen damals - vor der Zeit der Rote [sic.] Armee Fraktion RAF - wenn sie inhaltlich vermittelbar waren. $(B f, 45)$

Through repetition of the noun 'Frauen' (alone and in compound form) and the modal verb 'sollen', Perincioli insists on a feminist reading of these practices here. Repeated use of the verb 'sollen' and the final sentence draw attention to the communicative dimension to violence as 
cultural performance or even as language. Understanding violence as a language was certainly part of wider leftist discourses at that time: in the 'Gewalt' article of June 1968, the authors discussed 'die Sprache des Systems'; 'die Sprache ist die Gewalt.' ${ }^{67}$ Fanon had also alluded to the communicative dimension to violence and counter-violence. ${ }^{68}$

For Perincioli, not only did women's militant practices raise feminist awareness, they were also key to the cultivation of feminist identities through the changing of gendered codes of behaviour and gendered roles. The quotation above and other references to militant activism appear in the chapter 'Frauenkommune Cosimaplatz (1971): Vier Frauen auf dem Kriegspfad / Suche nach neuem Verhalten und Frauenbild / die “Bewegung 2. Juni” entsteht' (Bf, 41-48; my italics), which has subheadings such as 'Eine "neue Identität als Frauen”' and "'Verweigerung der Anpassung”' ( $B f, 43)$. For a woman, then, Perincioli suggests, militant (violent) behaviour was an important part of this feminist transformation of the self.

That idea recalls Fanon's notion of the transformative and self-actualizing potential of counter-violence in the context of French colonial Algeria. Although Perincioli does not refer to Fanon's claims about the humanizing potential of counter-violence, she makes explicit reference to him and his text Les Damnés de la Terre in all of her publications, in particular in her discussion of the Black Panther Party who, she asserts, drew their inspiration from Fanon. Echoing the 'Gewalt' article, Perincioli’s own investment in the Black Panther Party as 'Vorbild einer solchen Selbstermächtigung' is clear, not least in the affective quality of her descriptions: 'Mich elektrisierten die Bilder dieser Schwarzen [...] die nun stolz, kontrolliert und bewaffnet auf ihren Rechten bestanden.' Perincioli draws parallels between Fanon's discussion of the effects of colonial violence on native Algerians, black Americans and the situation of women in 1970s’ West Germany: ‘Die Parallelen zum Verhalten von Frauen schienen unübersehbar’ (Bf, $51)$.

Reflecting on the activism around her women's commune in particular, Perincioli makes explicit the connection between women's militant violence and feminist transformations of the self, helping us to gender Fanon's notion of the transformative potential of counter-violence:

Militanz erfüllte für uns Frauen [...] einen anderen Zweck: Wir probten ein neues Rollenverständnis. Wir zeigten: Frauen hören auf zu lächeln, zu bitten und Verständnis zu üben - sie zeigen Zähne. Wir lernten Karate und sahen uns schon nach der ersten Lektion in eine Kneipenschlägerei verwickelt. ${ }^{69}$

For Perincioli, then, when women 'do' violence, it allows them to break out of their typically feminine socialization as passive, demure and decorative; it allows them to change the gendered scripts for women in highly productive feminist ways. Repeated use of the pronouns 'wir' and 
'uns' here suggests that this militant violence is productive beyond the individual woman, at the level of the feminist group. Further, the second sentence, with its alliterative ' $z$ ' and sense of crescendo in the listing of what violence was 'doing' for women, reaching a climax in the alliterative and aggressive ‘zeigen Zähne’, evokes Perincioli’s pleasure and investment in militant violence, at least as it is retrospectively narrated.

These qualities are arguably part of the reason why female militancy had such infectious, thrilling appeal for other, even non-political women, perhaps with the potential to politicize them. The quotation above is preceded by the following: 'Und das weibliche Publikum war begeistert auch unpolitische Frauen ließen sich hinreißen von dem Kitzel, dass es in der Stadt Frauen gab, die zuschlugen. ${ }^{70}$ Violence, constructed again as a sort of cultural performance here (it has a 'Publikum'), is accorded an overwhelming and uncontrollably affective power through the verb 'hinreißen' and the noun 'Kitzel', which could also suggest that these women did not take militancy seriously enough, or fully understand its intended political meaning.

The affective investment in violence narrated here is, I would argue, gender specific, at least in part: the 'female public' are 'begeistert' and 'hingerissen' precisely because women are not socialized to be criminal or violent, arguably unlike men. ${ }^{71}$ As Bat-Ami Bar On contends in her discussion of the cultivation of violent bodies in the context of self-defence: '[The production of the violent female body] is a production of bodies that break a taboo and are as a result disobedient and transgressive because as implements of violence, they are skilled and competent in ways that are usually reserved for men. ${ }^{72}$ Violence can be a sensuously attractive, thrilling force for women as well as for men, on account of the fact that it tends to represent a transgression of the law, of class boundaries, of what is considered 'appropriate behaviour', and because one never knows what its consequences might be. However, there is arguably an additional allure, additional pleasure, but also additional anxiety, in women's perpetration of violence, because of that transgression of gendered boundaries. Reflecting in 1977 on the 'phenomenon' of women and terrorism, Alice Schwarzer draws similar conclusions: 'Frauen, denen jahrtausendelang Friedfertigkeit und Erdulden um jeden Preis gepredigt und Gewalt verboten wurde - Frauen sind vielleicht noch stärker als Männer fasziniert von der Gewalt wenn sie sie einmal wagen., 73

The feminist transformation of the self through violence has important class dimensions, too, according to Perincioli: it is not just about shedding feminine socialization, but rather shedding middle-class feminine socialization: 'Diese Verweigerung', she insists, 'bestand für mich hauptsächlich darin, meine Erziehung als höhere Tochter abzulegen’ (Bf, 43). Again, pleasure in that transgression of boundaries is narrated: 
Ich verspürte große Lust, meine Höhere-Töchter-Sozialisation loszuwerden: Unvergesslich blieb mir deshalb, wie ich zu diesem Zwecke als Erstes einen katholischen Aktenschrank knackte. All dies ergab ein schwirrendes Gefühl, dass alle Schranken, die unsereins von den anderen Klassen trennten, ganz leicht fallen können. $(B f, 21)$

Arguably because of the sensuous thrill of transgressing gendered, class and other boundaries, and what this does for the self, militant violence can have a dangerously seductive allure. ${ }^{74}$ It can threaten to become an end in itself, taking on a dizzying momentum of its own. Perincioli selfcritically explains:

Die Politik unserer Frauenkommune reduzierte sich auf 'Aktionismus'. Wir versuchten durch anderes Verhalten und Grenzüberschreitungen herauszufühlen, in welche Richtung es möglicherweise weitergehen könnte. Ratlos waren wir zu allem bereit. So war es möglich, dass man bald das Militantere für das politisch Richtigere hielt. (Bf, 49)

Hence the seductive appeal of violent militant activism ('Militanz'), it would seem, was not just the preserve of West German men. ${ }^{75}$

Although Perincioli does not use the term (Gegen)gewalt herself, the militant violence she describes can be understood as feminist (Gegen)gewalt in three ways: first, in the sense of women directing physical violence/force against individual men, but also against capitalism/the state, increasingly being read as misogynistic and patriarchal but not yet gendered in a systematic way; second, because her ideas on militancy and its transformative potential are so clearly inspired by Fanon; third, on a symbolic level in the sense of the Gewalt of transgressing gendered social norms that can be read as both physically and symbolically/structurally/systemically violent in and of themselves. ${ }^{76}$ Indeed, Patricia Melzer suggests that we understand West German women terrorists precisely in terms of 'counterviolence' along these lines. Drawing on French phenomenologist Jean-Luc Nancy, Melzer explains:

rarely recognized to be at play here is their [women terrorists'] 'violent truth' [Nancy] - which assaults the gender regime, the system of meaning that explains and organizes gender norms [...]. Their 'violent truth' can [...] be understood as a very particular form of 'counterviolence,' as the gender regime's disciplinary technologies already inflict violence on lives. (DSYG, 11-12)

For Perincioli, the progressive potential of militant violence was specific to the historical time and place she describes: once the RAF and Bewegung 2. Juni had escalated their use of violence, feminist militant violence was no longer an effective feminist practice. 


\section{Violence against women and feminist '(Gegen)gewalt'}

By the mid-1970s, feminist (Gegen)gewalt can be identified in women's responses to violence against women in the context of the feminist 'discovery' of the pervasiveness of patriarchal violence in all its forms - physical, psychological, systemic, structural, symbolic, linguistic, state. The feminist practice of self-defence, but also the example of a planned retaliation to an incidence of rape, reveal how (Gegen)gewalt and the cultivation of an - at least potentially violent body ${ }^{77}$ can be productive in feminist ways. This is particularly so in a context in which women are overwhelmingly positioning themselves as victims of violence, which, it has been argued, takes away their sense of agency. At least that was how socialist feminist Frigga Haug understood what would become the at times totalizing claims of women's victim status ${ }^{78}$ and the dilemma that this poses in an article published in 1980:

Die Annahme, daß die Frauen ausschließlich Opfer sind [...], erweist sich als hoffnungslos, wenn man an ihre Veränderung, also an ihre Selbstbeteiligung bei ihrer Befreiung denken soll. Es bleibt ewig im Dunkeln, warum Befreiung möglich und notwendig ist und vor allem, wer sie eigentlich vollbringen soll, wie also - um es allgemeiner auszusprechen - eigentlich die Frauen als Opfer und Objekt in den Status eines Subjektes kommen. ${ }^{79}$

In 1974, rape as a feminist issue entered West German feminist discourse via the translation of an American article on rape in the third issue of Frauenzeitung, in March 1974. ${ }^{80}$ One year later, Susan Brownmiller's Against our Will, an analysis of rape as exemplary of systemic, rather than individual, male violence against women, sharpened feminist sensibilities to the systemic/structural nature of male and patriarchal violence. ${ }^{81}$ Meanwhile, the high-profile case of lesbian couple Marion Ihns and Judy Andersen, convicted in the autumn of 1974 for hiring a hitman to murder Ihns's husband, had contributed further to feminist awareness of this subject. On account of the misogynistic and homophobic way in which the couple were dealt with in the press and in court, this case became an important feminist issue. What is striking in feminist treatment of the case - and indicative of the emerging paradigm of 'violence as inherently patriarchal and women as the victims of violence' (DSYG, 58) - is how the two women were styled as the victims/objects rather than the perpetrators/subjects of violence, on account of the many forms of violence they had suffered. ${ }^{82}$

It was in 1976, however, that the subject of patriarchal violence reached its height. As Schwarzer would later comment: '[1976] rückt das Problem Gewalt ähnlich explosiv in das Bewußtsein der Öffentlichkeit, wie wenige Jahre zuvor das Thema Abtreibung. Plötzlich ist der Bann des Schweigens gebrochen. ${ }^{83}$ An important impulse was the International Tribunal of 
Crimes against Women that took place in Brussels in March 1976. That event was followed by the founding of the first German women's refuge in Berlin in November 1976. Even the tabloid Bild-Zeitung capitalized on this subject, with a series titled 'Mein Mann schlägt mich' ${ }^{84}$

Not surprisingly, women's self-defence and retaliations to instances of male violence do not tend to be described as Gewalt or Gegengewalt by feminists at this point; they prefer terms such as 'Gegenaktion' or 'physischer Widerstand', ${ }^{85}$ although interestingly the Ihns-Andersen case is referred to as Gegengewalt on occasion. (Gegen)gewalt, in this later context of terrorist violence and the RAF's self-declared war against the state, is overwhelmingly connoted negatively for feminists as patriarchal or as Mackermilitanz. ${ }^{86}$ However, the leftist notion of Gegengewalt had always had a reactive, rather than active, quality, used alongside terms such as 'Notwehr' and 'Widerstand', as discussed above. Furthermore, the bodily and political practices of women in this later context seem to be drawing on those same ideas of (Gegen)gewalt as transformative, discussed by Schrader-Klebert and Perincioli: the cultivation of a violent female body can be read in similarly productive and emancipatory ways for the female and feminist self at this point. Here we can identify not only the rewriting of gendered behavioural and emotional/affective scripts, but also the recoding or redisciplining, in the Foucauldian sense, ${ }^{87}$ of the gendered body as a violent body, something which can induce both pleasure and anxiety.

A booklet produced by the Berlin Frauenzentrum for the Brussels International Tribunal of Crimes Against Women in 1976 is indicative of the breadth of feminist understanding of patriarchal violence against women at this point, as captured in its title: Gewalt gegen Frauen in Ehe, Psychiatrie, Gynäkologie, Vergewaltigung, Beruf, Film und was Frauen dagegen tun. ${ }^{88}$ Characteristically, women are positioned primarily as the victims of patriarchal violence here. Amongst the plethora of articles on the different forms of violence that women are subjected to, ${ }^{89}$ however, is an article on self-defence, ${ }^{90}$ the reproduction of a poster on self-defence that shows a woman kicking a man directly in the groin, ${ }^{91}$ and six pages devoted to the 'violent' porn film Geschichte der $O$ and feminist militant activism around screenings of it: activism that, according to the reproduction of an article from the Abendpost zum Samstag, is no less violent/militant than that of the early 1970s described by Perincioli. ${ }^{92}$ Against this positioning of women primarily as victims/objects of violence, these three examples of women fighting back produce some muchneeded space to imagine feminist agency.

In the article on self-defence, the author describes how difficult it is for women to 'do' violence on account of the inhibitions they experience as a result of their socialization as women and the gendered disciplining of their bodies as non-violent bodies: 'Wir müssen unsere seit der Kindheit in uns eingepflanzte Hemmung vor körperlicher Auseinandersetzung überwinden.' 93 The naturalistic imagery here reinforces the power of those inhibitions. This is a recurring topic 
in feminist discussion of self-defence. In the first instalment of a Courage series on 'Selbstverteidigung' of 1977, complete with cut-out diagrams of how to carry out particular moves, martial arts teacher Martha couches this difficulty in terms of an 'unnatural' mental problem:

In den zwei Jahren, die ich Frauen in Karate ausbilde, habe ich gelernt, daß es nicht nur darauf ankommt, sich mit der Technik zu befassen, sondern auch mit den psychischen Problemen, die leider Göttin in fast jeder Frau drinnen stecken. Von Natur aus wehrt sich zwar jedes Wesen, doch den Frauen wird dies schon sehr früh ausgetrieben. Deshalb müssen wir unsere Angst, dem Angreifer Schmerz zuzufügen, abbauen, also lernen aggressiver und egoistischer zu werden. ${ }^{94}$

The author uses a discourse of pain rather than violence in a context in which the brutality of what she is describing could certainly justify the term Gewalt. ${ }^{95}$ The idea of a 'natural' tendency to defend oneself that is 'unnaturally' expelled ('ausgetrieben') recalls the reflections of French existentialist Simone de Beauvoir in her pioneering study Le Deuxième sexe of 1949. As she sees it, at around the age of 13 something quite significant happens in the gendered socialization of individuals: boys go through 'a real apprenticeship in violence' whilst girls 'give up rough games' with far-reaching consequences at the level of sovereignty/subjectivity/agency: 'In the adult world [...] brute force plays no great part in normal times, nevertheless, it haunts that world' and in such a world, a man can 'feel in his fists his will for self-affirmation', which 'reassure[s] him of his sovereignty'. She continues:

Violence is the authentic proof of each one's loyalty to himself, to his passions, to his own will [...]; anger or revolt that does not get into the muscles remains a figment of the imagination. It is a profound frustration not to be able to register one's feelings upon the face of the world. ${ }^{96}$

Although de Beauvoir is writing twenty-five years earlier, her reflections on the link between 'doing' violence and a sense of agency/sovereignty remain pertinent for the 1970s.

In a text written in 1980 on rape and the West German legal system, Ingrid Lohstöter describes the negative and self-destructive impact of this disciplining of the female body and psyche as non-violent, as well as the gendered behaviour that that leads to:

Es ist bekannt und oft beschrieben worden, wie wir Frauen in unserer Erziehung von Anfang an von körperlichen Auseinandersetzungen ferngehalten werden und zum Nachgeben, zur Höflichkeit und zur Passivität angehalten werden. Schon früh werden dadurch Aggressionen gegen andere unterdrückt, die sich dann selbstzerstörerisch nach innen richten. ${ }^{97}$ 
Lohstöter's reflections on women's internalizing of their aggression recall Schrader-Klebert's observations of 1969. Through practising karate, though, women can rediscipline their bodies and change gendered behavioural and emotional/affective scripts in positive feminist ways, she claims. This can lead to an increased sense of feminist consciousness. According to Kernke, the long-term feminist effects of karate are along these lines:

Karatetraining und das damit verbundene Körpertraining, die Schreie, die dazugehören, [ist] eine wichtige Sache bei unserer Bewußtwerdung als Frauen. Wir lösen uns von der verinnerlichten Passivität, lernen unsere Aggressionen nach außen, statt gegen uns selbst zu lenken oder in rein verbaler Form zu

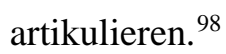

Kernke explicitly links the cultivation of a violent body to an increased feminist consciousness here, as well as reinforcing how the practice of karate can lead to changes in behavioural and affective scripts, including learning how to rechannel aggression. Looking back at the importance of self-defence for lesbian feminists in particular, Bärbel Düsel also describes the positive feminist effects of redisciplining the female body as violent body, though here termed as one capable of 'physische[m] Widerstand': 'Mit Stillhalten, Leisesein und Platzmachen sollte Mitte der 70er Jahre endlich Schluss sein. ${ }^{99}$ As such, the author understands the practice of selfdefence as always political, ${ }^{100}$ particularly for lesbian feminists, not least because, by encouraging an increased sense of lesbian identity/consciousness, lesbian feminists were further emboldened in their political practice:

Insbesondere der Kampfsport half bei der Identifikationsfindung von Lesben, weil diese oft in der Öffentlichkeit Angst hatten, sich zu zeigen, da sie mit massiver Anmache und gewalttätigen Übergriffen von Männern zu rechnen hatten. Sich im Kampfsport zu trainieren, sich mit anderen Lesben im Verein auszutauschen, auf den gemeinsamen Demos gemeinsame Stärke zu demonstrieren und sich aus eigener Kraft gegen Männergewalt zur Wehr setzen zu können, führte dazu, dass sich Lesben mehr und mehr trauten, offener und offensive und auch voller Stolz als Lesben aufzutreten. ${ }^{101}$

Because of this transgression of one's gendered socialization, this redisciplining of the gendered body, as well as the more general act of physical exertion, there is joy and pleasure in the practice of self-defence, not least in its communal dimension. As Kernke asserts: 'Die Beteiligung am Karatetraining mit Frauen und nur mit Frauen macht Spaß.' ${ }^{102}$ This pleasure and exhilaration, though productive, are also potentially dangerous. Perhaps telling in this regard is 
Martha's warning, in the second instalment of her Courage series, that you should only indulge in a 'Schlägerei' when it cannot be avoided:

Meidet - wenn es möglich ist - jede Schlägerei; geht solchen Situationen aus dem Weg. Jedes Handgemenge ist gefährlich. Das gilt besonders für die Frauen, die bereits eine Weile Karate und Jui Jitsu ausüben. Nach einer gewissen Zeit fühlt man sich sehr stark und sicher, man will sein Können ausprobieren und wartet direkt auf Anpöbelei. Manche Frauen provozieren sogar mit Worten. Diese Zeit ist sehr gefährlich, wenn die Frau sich überschätzt. ${ }^{103}$

Although Martha is explicitly only warning women against the desire to try out a technique ('sein Können'), I would argue that this warning is also indicative of that seductive appeal of violence and its exhilarating pleasures; those same pleasures that Perincioli alluded to with regard to militant activism, pleasures that are not particularly 'sayable' in general terms, let alone in a feminist context in which violence is the preserve of men/the patriarchy.

A text published in the second Frauenjahrbuch (Frauenjahrbuch '76), with a 47-page section on 'Gewalt gegen Frauen', testifies to those productive and pleasurable feminist dimensions of violence. In the 15-page article 'Antwort auf eine Vergewaltigung', five women narrate their experience of planning and executing an attack in Paris on the rapist of two of their group. As the women assert in the 'Nachwort', the article is intended as a call for women to develop similar militant/violent practices in a context in which women are overwhelmingly represented as victims:

Wir haben den Artikel geschrieben, weil es hauptsächlich nur Beispiele von Leid, Erniedrigung, Ausbeutung und Zerstörung von Frauen gibt, jedoch sehr wenig Möglichkeiten aufgezeigt werden, wie Frauen sich wehren können. Wir wollen andere Frauen anturnen, ähnliche oder ganz andere Formen der Gegenwehr zu entwickeln. ${ }^{104}$

Again, the women point to the difficulties of being violent due to a woman's socialization, but here that transgression induces anxiety. Ursula writes, using a discourse of pain rather than violence: 'Die Angst, jemandem weh zu tun, sitzt so tief'; and Ingrid: 'Meine Angst, alle zuvor gelernten Verhaltensweisen abzulegen, war noch größer, als mein Wille, mich zu wehren’ (AV, 215 and 212). There are pleasurable dimensions, too, to this attack, at least as it was imagined. Anne articulates the pleasurable affects she envisaged in 'doing' violence, even though she was unable to follow through: 'Ich wollte ihn schlagen, endlich eine sinnliche Befriedigung meines Hasses finden, es ging nicht' (AV, 206). Gisela writes of her feelings after arriving in Paris, and her - retrospectively narrated - excitement is palpable: 'Es war ein irres Gefühl: Wir sind 
wiedergekommen, wir werden den Kerl zu fassen kriegen, er wird diese Nacht nicht mehr lange zu seinen Erfolgen rechnen können. Wir waren auf einmal nicht nur fünf, sondern eine ganze Menge Frauen' (AV, 208). There is a breathless quality to the accumulation of clauses here, indicative of excitement. And the repetition of the pronoun 'wir' suggests the importance of the collective/communal dimensions to this attack. In fact, Gisela seems to be alluding to a sort of 'imagined community' of violent feminists created here for her. ${ }^{105}$ The importance of and pleasure in a communal dimension to the experience is also evident in the 'Nachwort': 'Wir haben eine Woche nichts anderes getan, als die Aktion geplant, vorbereitet und durchgespielt, haben fürchterlich viel Spaß dabei gehabt' (AV, 216). The effects of this collective violent experience, it would seem, are productive and transformative at the level of the group. Ursula asserts: 'die Parisaktion hat mich weitergebracht. Sehr stark auch dadurch, daß wir immer mehr zu einer Gruppe wurden' (ibid.). Fanon had observed the same cohesive quality of violence for the group with regard to Algeria: 'The practice of violence binds them together as a whole,' he asserts, 'since each individual forms a violent link in the great chain, a part in the great organism of violence which has surged upwards in reaction to the settler's violence in the beginning. ${ }^{106}$ The attack was also productive at the individual level. Anne explains that the rape had produced such an intense feeling of hatred in her, 'daß die einzige Möglichkeit, mich selbst und mein Selbswertgefühl zu erhalten, darin besteht, einfach zurückzuschlagen, endlich die Angst vor einer aggressiven Reaktion der Kerle loszuwerden, endlich ich selbst zu sein mit meiner Wut' (AV, 202). She narrates here the regaining of an authentic sense of self and of agency through the violent attack. She continues: 'Die Aktion hat mir eine ganze Portion Selbstvertrauen Männern gegenüber gegeben’ (AV, 206).

\section{Conclusion}

I have been tracing a cultural history of feminist (Gegen)gewalt and argued for an understanding of that discourse and practice as transformative, empowering and productive for the neue Frauenbewegung, at the levels both of the individual nascent feminist subject and of the movement as a whole. Although (Gegen)gewalt was framed as reactive rather than active, as it was within wider antiauthoritarian discourses, feminist (Gegen)gewalt denoted an important way of addressing power; it provided an active subject position that held both strength and pleasure; it helped solidify group identity beyond victim status, with a political agenda of resistance and change; and it played an important role in determining what women could 'be' and 'do' within the neue Frauenbewegung. We may hesitate to endorse violent, militant action and words. For feminist debate and as retrospectively written accounts show, however, it was important for some women to entertain the possibility of taking violent action. 
Beyond that, and as Patricia Melzer has shown, there is a scholarly, political and ethical need to write violence back into the neue Frauenbewegung, as I have been doing. West German feminists were clearly discussing and practising feminist (Gegen)gewalt long before the appearance of the militant feminist group Rote Zora, which is typically written out of the neue Frauenbewegung as discussed above, their militancy neatly bracketed off alongside that of terrorist groups: a useful technique, given how feminism is often blamed for the high incidence of women terrorists, as it was, particularly in the popular press, in the summer of $1977 .{ }^{107}$ In fact, it is that same feminist (Gegen)gewalt, I would suggest, that feeds into the self-understanding, and feminist motivations perhaps, of Rote Zora, a group that would constitute itself in the late 1970s. This is strongly suggested in the group's retrospective account, Mili's Tanz auf dem Eis, of 1990:

Wir selbst empfanden das Verlassen der uns zudiktierten weiblichen Friedfertigkeit bzw. die bewusste Entscheidung für gewalttätige Mittel in unserer Politik als ungeheuer befreiend. Wir erlebten, daß wir mit unseren Aktionen, Angst, Ohnmacht und Resignation durchbrechen konnten, und wollten dies anderen FrauenLesben weitervermitteln. ${ }^{108}$

\author{
Centre for Women's Studies \\ Grimston House \\ University of York \\ York YO10 5DD \\ United Kingdom \\ clare.bielby@york.ac.uk
}

\title{
ACKNOWLEDGEMENTS
}

I would like to thank the two anonymous readers for their constructive feedback, and Nadia Atia for discussions on Fanon and race.

\section{NOTES}

\footnotetext{
${ }^{1}$ West Germany's ‘second-wave’ feminist movement is also termed die autonome Frauenbewegung. According to Ilse Lenz, the movement should be referred to in the plural to account for the diversity of positions. Ilse Lenz, 'Die unendliche Geschichte? Zur Entwicklung und den Transformationen der Neuen Frauenbewegungen in Deutschland', in Die Neue Frauenbewegung in Deutschland. Abschied vom kleinen
} 
Unterschied. Ausgewählte Quellen, ed. by Ilse Lenz (Wiesbaden: VS-Verlag, 2009), pp. 9-28. I shall use the spelling die neue Frauenbewegung throughout.

${ }^{2}$ Lenz divides the movement(s) into four phases: 1: 'Die Bewusstwerdungs- und Artikulationsphase (1968-1975)'; 2: 'Die Phase der Pluralisierung und Konsolidierung (1976-1980)'; 3: 'Die Phase der Professionalisierung und institutionellen Integration (1980-1989)'; 4: ‘Die Phase der Internationalisierung, deutschen Vereinigung und Neuorientierung (1989-2000). Lenz, 'Die unendliche Geschichte?', pp. 11-16.

${ }^{3}$ See for example Changing the World, Changing Oneself: Political Protest and Collective Identities in West Germany and the U.S. in the 1960s and 1970s, ed. by Belinda Davis and others (New York and Oxford: Berghahn, 2010).

${ }^{4}$ Sarah Haffner, “'Die Frauen waren der revolutionärste Teil dieser etwas revolutionären Bewegung”. Sarah Haffner. Die Kunst als Weg zu sich selbst', in Die 68erinnen. Porträt einer rebellischen Frauengeneration, ed. by Ute Kätzel (Berlin: Rowohlt, 2002), pp. 141-59 (p. 151).

${ }^{5}$ Ute Kätzel, 'Vorwort', in Die 68erinnen, ed. by Kätzel, pp. 9-18 (p. 9).

${ }^{6}$ I visited the Hamburger Institut fur Sozialforschung (HIS), the FrauenMediaTurm in Cologne, and FFBIZ - das feministische Archiv in Berlin.

${ }^{7}$ Frantz Fanon, The Wretched of the Earth, trans. by Constance Farrington (London: Penguin, 2001 [1961]). Herbert Marcuse, ‘Repressive Tolerance’, in A Critique of Pure Tolerance, ed. by Robert Paul Wolff, Barrington Moore Jr. and Herbert Marcuse (Boston: Beacon Press, 1969 [1965]), pp. 95-137. ${ }^{8}$ Dutschke used the term in a Spiegel interview in 1967. “Wir fordern die Enteignung Axel Springers”. Spiegel-Gespräch mit dem Studenten Rudi Dutschke (SDS)’, Der Spiegel, 29 (1967), 30-33.

${ }^{9}$ Ulrike Meinhof, 'Gegen-Gewalt', konkret, 2 (1968), 2-3; reprinted in Ulrike Meinhof, Deutschland Deutschland unter anderem. Aufsätze und Polemiken (Berlin: Wagenbach, 1995), pp. 126-29.

${ }^{10}$ For example, Meinhof uses the term 'Notwehr' in her 'Gegen-Gewalt' article, and the term 'Widerstand', with its strong associations with heroic anti-Nazi resistance, in her article 'Vom Protest zum Widerstand' of May 1968. Ulrike Meinhof, 'Vom Protest zum Widerstand', konkret, 5/1968, 5; reprinted in Ulrike Meinhof, Die Würde des Menschen ist antastbar. Aufsätze und Polemiken (Berlin: Wagenbach, 1995), pp. 138-41.

${ }^{11}$ See Berliner Redaktionskollektiv, 'Gewalt’, konkret, 6 (1968), 24-28, 35.

${ }^{12}$ Patricia Melzer, Death in the Shape of a Young Girl: Women's Political Violence in the Red Army Faction (New York and London: New York University Press, 2015). Other notable exceptions (in addition to Melzer) to this tendency to 'write out' feminists' ambivalent relationship to Gewalt include Cristina Perincioli, Berlin wird feministisch. Das Beste, was von der 68er Bewegung blieb (Berlin: Querverlag, 2015) and Katharina Karcher, 'Sisters in Arms? Female Participation in Leftist Political Violence in the Federal Republic of Germany since 1970’ (unpublished doctoral thesis, University of Warwick, 2013). See also the special issue on Gegengewalt in the lesbian-feminist journal Ihrsinn, 16 (1997). My article 
follows all of these studies. Further references will be given in the text, using the following abbreviations, each followed by the page number: Melzer (DSYG), Perincioli (Bf).

${ }^{13}$ Cultural feminism developed in West Germany in the context of the feminist campaign around patriarchal violence against women, the escalation of militant and state violence (particularly during the so-called Deutscher Herbst of 1977), and the emergence of the peace movement in the later 1970s.

${ }^{14}$ As Katharina Karcher points out, 'With the exception of Ilse Lenz (2010), feminist historians of the German women's movement have ignored the group.' Katharina Karcher, 'How (Not) to "Hollaback”: Towards a Transnational Debate on the "Red Zora" and Militant Tactics in the Feminist Struggle Against Gender-Based Violence', Feminist Media Studies, 16.1 (2015), 70-85 (72).

${ }^{15}$ See, for example, Michael Meuser, “'Doing Masculinity” - Zur Geschlechtslogik männlichen Gewalthandelns', in Gewaltverhältnisse. Feministische Perspektiven auf Geschlecht und Gewalt, ed. by Regina-Maria Dackweiler and Reinhild Schäfer (Frankfurt a.M.: Campus, 2002), pp. 53-78.

${ }^{16}$ Christopher Coker, Waging War without Warriors? The Changing Culture of Military Conflict (Boulder, CO: Rienner, 2002), p. 6.

${ }^{17}$ Karin Schrader-Klebert, 'Die kulturelle Revolution der Frau', Kursbuch, 17 (1969), 1-45. Further references will be given in the text as KRF followed by the page number.

${ }^{18}$ Alice Schwarzer, So fing es an! 10 Jahre Frauenbewegung (Cologne: Emma-Frauenverlag, 1981), p. 121.

${ }^{19}$ Detlef Siegfried, 'White Negroes: The Fascination of the Authentic in the West German Counterculture of the 1960s', in Changing the World, Changing Oneself, ed. by Davis and others, pp. 191-213 (p. 210). ${ }^{20}$ As Maria Höhn argues, leftist activists were "completely oblivious to the sensibilities of the soldiers [in West Germany] who wanted to be identified as "Blacks” or "Afro-Americans” and passionately denounced the use of the term “Negro” or “Neger” as racist.' Maria Höhn, 'The Black Panther Solidarity Committee and the Trial of the Rammstein 2', in Changing the World, Changing Oneself, ed. by Davis and others, pp. 215-39 (p. 221). On feminist universalism within the neue Frauenbewegung, see Quinn Slobodian, 'Guerilla Mothers and Distant Doubles: West German Feminists look at China and Vietnam, 1968-1982’, Studies in Contemporary History, 12 (2015), 39-65.

21 'Die Situation der Frau gleicht der des Negers in Amerika, aber ihre Strategie muß eine andere sein, weil sie anders an ihren Unterdrücker gebunden ist.' Schrader-Klebert, KRF, p. 2.

${ }^{22}$ Kätzel, 'Vorwort', pp. 11, 16. As Kätzel's volume reveals, the scope for feminine/feminist political subjective positions in the mid- to late 1960s was a little more diverse than that. See in particular Sigrid Fronius's and Susanne Schunter-Kleemann's contributions in Die 68erinnen, pp. 21-39 and pp. 101-19. ${ }^{23}$ Alice Schwarzer, Der 'kleine Unterschied' und seine großen Folgen (Frankfurt a.M.: Fischer, 1984 [1975]), p. 232.

${ }^{24}$ Helke Sander, ‘1. versuch, die richtigen fragen zu finden’ (02.68), Hamburger Institut für Sozialforschung (HIS), Ordner SBe 200 (Frauenbew. i.d. Politik). Sander's orthography here is typical of the writing of the antiauthoritarian movement. 
${ }^{25}$ Helke Sander, ““Nicht Opfer sein, sondern Macht haben”. Helke Sander. Mitbegründerin des Aktionsrats zur Befreiung der Frauen’, in Die 68erinnen, ed. by Kätzel, pp. 161-79 (p. 173).

${ }^{26}$ Schwarzer, So fing es an!, p. 8.

${ }^{27}$ Frantz Fanon, Die Verdammten dieser Erde (Berlin: Rowohlt, 1971 [1966]). The first section of that text, 'Concerning Violence', had already been published in Kursbuch's second issue of 1965.

${ }^{28}$ Jean-Paul Sartre, 'Preface’, in Fanon, The Wretched of the Earth, pp. 7-26 (p. 18).

${ }^{29}$ Fanon, The Wretched of the Earth, pp. 73, 74.

${ }^{30}$ Ibid., p. 28.

${ }^{31}$ Sartre, 'Preface', p. 18.

${ }^{32}$ Berliner Redaktionskollektiv, 'Gewalt’, p. 35. See Sarah Colvin, 'A Guilty Text? Violence as

Conceived by an Authors' Collective around Ulrike Meinhof in 1968, and the Question (Again) of the Relationship between '68ers and the RAF', Tel Aviver Jahrbuch für deutsche Geschichte, 42 (2014), 18196 (pp. 190-93).

${ }^{33}$ Colvin, ‘A Guilty Text?’, p. 195.

${ }^{34}$ Berliner Redaktionskollektiv, 'Gewalt’, p. 35.

35 'Das unglückliche Bewusstsein' is a Hegelian notion.

36 'Wir sind neidisch und wir sind traurig gewesen’ (15.01.68), HIS, Ordner SBe 200 (Frauenbew. i.d. Politik).

${ }^{37}$ Sander, '1. versuch, die richtigen fragen zu finden'.

${ }^{38}$ Meinhof, 'Gegen-Gewalt'.

${ }^{39}$ Meinhof, 'Vom Protest zum Widerstand’, 5.

${ }^{40}$ Colvin, ‘A Guilty Text?’, p. 185.

${ }^{41}$ Berliner Redaktionskollektiv, 'Gewalt’; Colvin, 'A Guilty Text?’.

42 'brief an die westdeutschen genossinnen’ (11.68), FFBIZ, Ordner A Rep 400. Berlin 20. Aktionsrat (1). The letter was written shortly after the notorious Schlacht am Tegeler Weg of November 1968, which had led to a further escalation of violence.

${ }^{43}$ See for example the entry under 'Frauenbewegung' on the website of the Bundeszentrale für politische Bildung: <http://www.bpb.de/gesellschaft/gender/frauenbewegung/35287/neue-welle-im-westen?p=all> [accessed 29 October 2015].

${ }^{44}$ Helke Sander, 'Rede des “Aktionsrates zur Befreiung der Frau”', reprinted in Frauenjahrbuch '75 (Frankfurt a.M.: Roter Stern, 1975), pp. 10-15 (p. 11).

${ }^{45}$ Schrader-Klebert cites Helke Sander twice: Sander’s ‘Referat auf der SDS Delegiertenkonferenz im September 1968’ (KRF, 42); and Sander’s ‘Resolution zur Emanzipation der Frauen, SDS

Delegiertenkonferenz September 1968’ (KRF, 43).

${ }^{46}$ Ulrike Meinhof, 'Die Frauen im SDS oder In eigener Sache', konkret, 12/1968, 5.

${ }^{47}$ Meinhof, 'Gegen-Gewalt’. See Sarah Colvin, Ulrike Meinhof and West German Terrorism: Language, Violence, and Identity (Rochester, NY: Camden House, 2009), pp. 32-33. 
${ }^{48}$ Sigrid Rüger was not a member of the Aktionsrat zur Befreiung der Frau and her actions, according to Sander, did not even have a feminist motivation. See Sander, “"Nicht Opfer sein, sondern Macht haben”, p. 169. I agree with Patricia Melzer, in Death in the Shape of a Young Girl, that an action does not have to be undertaken by a self-consciously feminist subject to be understood as a feminist practice.

${ }^{49}$ See for example Kai Hermann, 'Was denn nun, Genossen? Delegiertentagung des SDS: Die Revolte entläßt ihre Kinder’, Die Zeit (1968): <http://www.frauenmediaturm.de/themen-portraets/chronik-derneuen-frauenbewegung/vorfruehling-1968-1970/zeit/> [accessed 29 October 2016].

50 'Selbstverständnis des Aktionsrates zur Befreiung der Frau’ (16.10.68), HIS, Ordner SBe 200 (Frauenbew. i.d. Politik).

${ }^{51}$ According to Sander: 'In allen Städten, aus denen SDS-Vertreter nach Frankfurt gekommen waren, gründeten sich Frauengruppen.’ Sander, ““Nicht Opfer, sondern Macht haben”’, p. 169.

52 'Der Weiberrat im SDS’, Frauenjahrbuch ’75, pp. 15-18 (p. 16).

53 'Mädchen-Demonstration zum Frauen-Wahlrecht', Frankfurter Rundschau, 14 October 1968, FFBIZ, Ordner A Rep 400. Berlin 20. Aktionsrat (1).

${ }^{54}$ Flugblatt, HIS, Ordner SBe 200 (Frauenbew. i.d. Politik).

${ }^{55}$ Sarah Haffner, for example, has explained: 'Das “Schwänzeflugblatt” war für mich damals an der Grenze. Ich hielt es für geschmacklos’. Haffner, “'Die Frauen waren der revolutionärste Teil dieser etwas revolutionären Bewegung”, pp. 150-51.

${ }^{56}$ Cited in 'Der Weiberrat im SDS', p. 18.

${ }^{57}$ See, for example, the collection of essays, Wie weit flog die Tomate? Eine 68erinnen-Gala der Reflexion, ed. by Heinrich Böll Stiftung and das Feministische Institut (Berlin: Heinrich Böll Stiftung, 1999), based on a congress of the same name that took place in October 1998.

${ }^{58}$ In the Stern edition of 6 June 1971, 374 famous and non-famous women declared 'wir haben abgetrieben'. 'Wir haben abgetrieben.' Stern, 24 (1971), no. 24 (6 June 1971), pp. 16-23.

${ }^{59}$ Schwarzer, So fing es an!

${ }^{60}$ Cristina Perincioli, ‘Anarchismus $\rightarrow$ Lesbianismus $\rightarrow$ Frauenzentrum', in Wie weit, pp. 98-117;

'Warum musste die Tomate so weit fliegen? Über 68erInnen, Anarchismus, Lesbianismus bis zum Frauenzentrum', in In Bewegung bleiben. 100 Jahre Politik, Kultur und Geschichte von Lesben, ed. by Gabriele Dennert, Christiane Leidinger and Franziska Rauchut (Berlin: Querverlag, 2007), pp. 62-67. ${ }^{61}$ Perincioli is highly critical of socialist feminist groups, in particular their rather introspective retreat into theory and their failure to prioritize women's oppression over class oppression.

${ }^{62}$ Agit 883, 56 (16 April 1970): <http://www.agit883.infopartisan.net> [accessed on 13 January 2016].

${ }^{63}$ Valerie Solanas, SCUM Manifesto (Oakland, CA: AK Press, 2013 [1967]).

${ }^{64}$ Agit 883, 56.

65 The speech was made by Mao in 1944. See Colvin, Ulrike Meinhof, p. 99.

${ }^{66}$ Dem Volk dienen. In Rote Armee Fraktion. Texte und Materialien zur Geschichte der RAF, ed. by Martin Hoffmann (Berlin: ID-Verlag, 1997), pp. 112-44. 
${ }^{67}$ Berliner Redaktionskollektiv, 'Gewalt', 25.

68 'The violence of the colonial regime and the counter-violence of the native balance each other and respond to each other in an extraordinary reciprocal homogeneity.' Fanon, The Wretched of the Earth, p. 69.

${ }^{69}$ Perincioli, 'Warum musste die Tomate so weit fliegen?’, p. 64.

${ }^{70}$ Ibid.

${ }^{71}$ In “'Doing Masculinity”', Meuser contends that 'doing' violence is a key part of 'doing masculinity'. Messerschmidt argues that 'doing' crime is a way to achieve masculinity. See James Messerschmidt, Masculinities and Crime: Critique and Reconceptualization of Theory (Lanham, MD: Rowman and Littlefield, 1993).

${ }^{72}$ Bat-Ami Bar On, The Subject of Violence: Arendtean Exercises in Understanding (Lanham, MD: Rowman and Littlefield, 2002), p. 159.

${ }^{73}$ Alice Schwarzer, ‘Terroristinnen', Emma (October 1977), p. 5.

${ }^{74}$ Jack Katz, Seductions of Crime: Moral and Sensual Attractions in Doing Evil (New York: Basic Books, 1988). Katz is interested in the phenomenological dimensions of crime.

${ }^{75}$ Joschka Fischer, 'Vorstoß in “primitivere” Zeiten. Befreiung und Militanz', Autonomie, 5 (1977), 5264.

${ }^{76}$ See Judith Butler, Gender Trouble: Feminism and the Subversion of Identity (New York: Routledge, 1999 [1990]), p. xix.

${ }^{77}$ Bar On reads the female body in the context of self-defence as a violent body (The Subject of Violence, pp. 149-66).

${ }^{78}$ An article in the feminist journal Emma in the spring of 1977 will claim: 'wir alle sind geschlagene Frauen’. See Schwarzer, So fing es an!, p. 81.

${ }^{79}$ Frigga Haug, ‘Opfer oder Täter? Über das Verhalten von Frauen’, in Die Neue Frauenbewegung, ed. by Lenz, pp. 55-59 (p. 57).

80 'Vergewaltigung: Eine Form der sexuellen Unterdrückung der Frau’, Frauenzeitung: Frauen gemeinsam sind stark, 3 (1973), 4-6, HIS, AZF156, 156-834.

${ }^{81}$ The text would not be published in German until 1977, when it was also serialized in Emma. Susan Brownmiller, Against our Will: Men, Women and Rape (London: Secker and Warburg, 1975).

${ }^{82}$ See Clare Bielby, ““An jeder Straßenecke könnte praktisch ein Mannweib mit Schlagring, Lederkleidung und rauer Stimme auf ihn warten”: Gewalt, Weiblichkeit und Sexualität in der Bundesrepublik der 1970er Jahre’, Jahrbuch der Sexualitäten (2017), forthcoming.

${ }^{83}$ Schwarzer, So fing es an!, p. 80.

${ }^{84}$ See Schwarzer, ibid.

${ }^{85}$ Helga Kernke, 'Wie kann frau sich gegen physische Gewalt wehren', in Gewalt gegen Frauen in Ehe, Psychiatrie, Gynäkologie, Vergewaltigung, Beruf, Film und was Frauen dagegen tun (1975/76), pp. 1012 (p. 11), FFBIZ, Mappe BRD 20 Sander-Sammlung, 75-98; Bärbel Düsel, 'Wir sind Lesben, wir sind 
viele, und wir haben die Schnauze voll: Lesben verteidigen sich selbst', in In Bewegung, ed. by Dennert, Leidinger and Rauchut, pp. 195-97 (p. 195).

${ }^{86}$ In her discussion of the mid-1970s, Karrin Hanshew contends that feminists 'explicitly criticize[d] counterviolence as a macho myth’. Karrin Hanshew, Terror and Democracy in West Germany (Cambridge: Cambridge University Press, 2012), p. 185.

${ }^{87}$ Michel Foucault, Discipline and Punish: The Birth of the Prison, trans. by Alan Sheridan (London: Penguin, 1991 [1975]).

${ }^{88}$ Gewalt gegen Frauen in Ehe, Psychiatrie, Gynäkologie, Vergewaltigung, Beruf, Film und was Frauen dagegen tun (1975/76), FFBIZ, Mappe BRD 20 Sander-Sammlung, 75-98.

${ }^{89}$ For example, the reproduction of a tabloid article entitled 'Das Mädchen ist zu häßlich, das schlagen wir tot’, Gewalt gegen Frauen, p. 9.

${ }^{90}$ Kernke, 'Wie kann frau sich gegen physische Gewalt wehren'.

${ }^{91}$ Gewalt gegen Frauen, p. 45.

92 'Großer Wirbel um drei Kinos in Berlin unter Polizeischutz. Sauerkraut, Farb-Eier und Stinkbomben: Frauen protestieren gegen “Geschichte der O”; reproduced in Gewalt gegen Frauen, p. 48.

${ }^{93}$ Kernke, 'Wie kann frau sich gegen physische Gewalt wehren’, p. 10.

${ }^{94}$ Martha, 'Serie: Selbstverteidigung', Courage: Berliner Frauenzeitung, 2 (1977), no. 4, 8-9 (p. 8).

95 'Wir schocken, indem wir ihn anschreien, anspucken, schlagen, treten oder stoßen. Wir verwenden dabei unsere Fäuste, Ellenbogen, den Kopf, die Knie, Füße und Gegenstände, die wir gerade bei uns haben. Unsere Schläge und Stöße müssen auf empfindliche Körperteile gerichtet sein’. Ibid.

${ }^{96}$ Simone de Beauvoir, The Second Sex (New York: Bentam, 1961 [1949]), pp. 308-09.

${ }^{97}$ Ingrid Lohstöter, 'Wann eine Vergewaltigung für die deutsche Justiz eine Vergewaltigung ist', in Die Neue Frauenbewegung, ed. by Lenz, pp. 215-20 (p. 218).

${ }^{98}$ Kernke, ‘Wie kann frau sich gegen physische Gewalt wehren’, pp. 10-11.

${ }^{99}$ Düsel, ‘Wir sind Lesben’, p. 195.

${ }^{100}$ Ibid., p. 197.

101 Ibid.

${ }^{102}$ Kernke, ‘Wie kann frau sich gegen physische Gewalt wehren’, p. 11.

${ }^{103}$ Martha, 'Serie: Selbstverteidigung', Courage: Berliner Frauenzeitung, 2 (1977), no. 5, 24-25 (p. 24).

104 'Antwort auf eine Vergewaltigung', in Frauenjahrbuch '76 (Munich: Frauenoffensive, 1976), pp. 20216 (p. 216). Further references are given in the text as AV followed by the page number.

${ }^{105}$ Benedict Anderson, Imagined Communities: Reflections on the Origin and Spread of Nationalism (London: Verso, 1983).

${ }^{106}$ Fanon, The Wretched of the Earth, p. 73.

${ }^{107}$ On print-media representations of women terrorists, see Clare Bielby, Violent Women in Print:

Representations in the West German Print Media of the 1960s and 1970s (Rochester, NY: Camden House, 2012). 
${ }^{108}$ Mili’s Tanz auf dem Eis (1990): <http://www.freilassung.de/div/texte/rz/milis/milis1.htm> [accessed 12 May 2016].

[CLARE BIELBY

WEST GERMANY'S NEUE FRAUENBEWEGUNG]

[Figure 1: Front page of the flyer produced for the SDS delegate conference in Hanover, November 1968.] 